Original Research Article

\title{
Combined anticonvulsant effect of nifedipine and pentazocine in experimentally induced seizures in rats
}

\author{
Santosh K. Banjara ${ }^{1 *}$, Balakrishna Namala ${ }^{1}$, Rajanna Ajumeera ${ }^{2}$
}

${ }^{1}$ Department of Pharmacology, Osmania Medical College, Koti, Hyderabad, Telangana, India ${ }^{2}$ Department of Cell and Molecular Biology, ICMRNational Institute of Nutrition, Hyderabad, Telangana, India

Received: 01 June 2019

Revised: 29 June 2019

Accepted: 02 July 2019

*Correspondence to:

Dr. Santosh K. Banjara,

Email: drsantoshkumar999@ gmail.com

Copyright: (C) the author(s), publisher and licensee Medip Academy. This is an openaccess article distributed under the terms of the Creative Commons Attribution NonCommercial License, which permits unrestricted noncommercial use, distribution, and reproduction in any medium, provided the original work is properly cited.

\begin{abstract}
Background: Epilepsy is one of the common disorders of human with a prevalence of approximately $1 \%$ of the total population. Majority of seizures can be controlled with available antiepileptic drugs, about $20 \%$ of them still remain resistant to treatment. Recognizing this, there is a need to develop newer antiepileptic drugs with therapeutic potential. Present work is based upon the production of convulsions by maximal electroshock in rats. Evaluation of combined anticonvulsant effect of nifedipine and pentazocine on the duration of convulsion and duration of tonic hind limb extension and recovery in rats.

Methods: The study was commenced after obtaining approval from IAEC, Department of Pharmacology, Osmania Medical College, Koti, Hyderabad. All the wistar rats were induced convulsions by Maximal Electro-Shock (MES) method and rats showing tonic hind limb extension response were randomised into four groups (six animals in each group). Group 1 received distilled water, group 2 treated with nifedipine $10 \mathrm{mg} / \mathrm{kg} \mathrm{BW}$, group 3 treated with pentazocine $30 \mathrm{mg} / \mathrm{kg} \mathrm{BW}$ and group 4 treated with both nifedipine $10 \mathrm{mg} / \mathrm{kg} \mathrm{BW}$ and pentazocine $30 \mathrm{mg} / \mathrm{kg} \mathrm{BW}$. Drug administered by intraperitoneal route. The data analysed using ANOVA and group means with LSD Post Hoc Test. p-values $<0.05$ were considered as significant.
\end{abstract}

Results: When nifedipine and pentazocine were combined, the mean duration of convulsions, tonic hind limb extension and recovery were significantly decreased compared to control, nifedipine and pentazocine.

Conclusions: The results obtained in this study provide supporting pharmacological evidence of efficacy, possible potential benefit of combining nifedipine with pentazocine in epilepsy.

Keywords: Electroconvulsometer, Epilepsy, Nifedipine, Pentazocine

\section{INTRODUCTION}

Epilepsy is one of the common disorders of human with a prevalence of approximately $1 \%$ of the total population. Epileptic seizures have been known to represent an occasional discharge in the nervous tissue characterized by recurrent paroxysmal changes in the neurological function caused by abnormalities in the electrical activity of the brain. Epilepsy affects an estimated 7 million people in India and 50 million worldwide. The prevalence of epilepsy is $0.7 \%$ in India. The W.H.O has estimated that approximately $80 \%$ of the people with epilepsy live in developing countries and most of them do not get adequate medical treatment. ${ }^{1}$

A large number of promising compounds are currently undergoing preclinical and clinical evaluation and several of these will undoubtedly become meaningful additions to neurologist's pharmacological armamentarium. ${ }^{2}$

However, a series of new compounds have become available in 1990's. ${ }^{1}$ In spite of the vast number of drugs 
introduced for treatment of epilepsy, there is still a need for an ideal antiepileptic agent with properties like broad spectrum activity, rapid onset of action, least side effects, good oral bioavailability and at low cost. ${ }^{3}$

The entry of calcium into neurons seems to play an important role in epileptogenesis. The use of calcium channel blockers in treatment of seizures may be successful. ${ }^{4}$

Agonist action at kappa receptors in the brain results in maximal electroshock seizure protection and suggests that an endogenous kappa opioid system may be an important in the regulation of cerebral excitability. ${ }^{5}$

Present work is based upon the production of convulsions by maximal electroshock in rats. Evaluation of anticonvulsant effect of nifedipine, a calcium channel blocker and pentazocine an opioid analgesic, and combined anticonvulsant effect of nifedipine and pentazocine on the duration of convulsion and duration of tonic hind limb extension and recovery in rats.

Majority of seizures can be controlled with available antiepileptic drugs, about $20 \%$ of them still remain resistant to treatment. Recognizing this, there is a need to develop newer antiepileptic drugs with therapeutic potential.

\section{METHODS}

\section{Drugs and chemicals}

Nifedipine (Depin by Zydus Cadila) available as $5 \mathrm{mg}$ capsule and Pentazocine (Fortwin by Ranbaxy) available as $1 \mathrm{ml}$ ampoule are used for anticonvulsant activity were purchased from authorised local pharmacy.

\section{Preparation of solutions}

The standard solution of nifedipine was prepared by dissolving $5 \mathrm{mg}$ of nifedipine capsule in $1 \mathrm{ml}$ of double distilled water at room temperature.

\section{Experimental animals}

Wistar rats weighing 150-200gms were procured from National Center for Laboratory Animal Sciences (NCLAS), ICMR-National Institute of Nutrition, Hyderabad after obtaining approval from Institutional Animal Ethics Committee (IAEC), Department of Pharmacology, Osmania Medical College, Koti, Hyderabad.

\section{Induction of Convulsions by Maximal Electro-Shock (MES) method}

Maximal Electro-Shock (MES) method is used for induction of seizures using Electro Convulsiometer (Techno Electronics). The instrument provides alternating current stimulus of 50 cycles per second. The electronic timing circuit contained in the apparatus automatically passes stimulus current for a present period, which may be varied from 0.1 to $1 \mathrm{sec}$. in the steps of $0.01 \mathrm{sec}$. The current variable from 0.25 to $360 \mathrm{MA},+10 \%$ is suitable for producing minimal and supra maximal seizures required in the assay of anti-convulsant and anti-epileptic drugs. ${ }^{6}$

In rats' seizures induced with an alternating current of 150 $\mathrm{mA}$ intensity for $0.2 \mathrm{sec}$ through corneal electrodes (before using, a drop of normal saline was applied to corneal electrodes). Various phases of seizures i.e., onset and type to recovery were noted and timed and the parameters like duration of convulsions, duration of hind limb extensions and postictal depression followed by recovery.

\section{Experimental Design}

Only those rats showing tonic hind limb extension response were used for the experiment and randomly divided into four groups (six rats in each group). The animals were allowed to food and water ad libitum both being withdrawn just prior to experimentation. The drug was administered by intra peritoneal route.

- Group-1: Control group was given $0.2 \mathrm{ml}$ of distilled water.

- Group-2: This group of rats was treated with nifedipine $10 \mathrm{mg} / \mathrm{kg} \mathrm{BW}$

- Group-3: This group of rats was treated with pentazocine $30 \mathrm{mg} / \mathrm{kg} \mathrm{BW}$

- Group-4: This group of rats was treated with nifedipine $10 \mathrm{mg} / \mathrm{kg} \mathrm{BW}$ and pentazocine $30 \mathrm{mg} / \mathrm{kg} \mathrm{BW}$

After 45 minutes of drug administration the animals were subjected to MES with an alternating current of intensity of $150 \mathrm{~mA}$ for 0.2 seconds through corneal electrodes. Rats were observed for the positive response. The positive response was considered when the tonic hind limb extension response was abolished or decreased.

\section{Statistical analysis}

Results were expressed as Mean \pm SD in each experimental group. Statistical analysis was performed using SPSS (Statistical Package for the Social Sciences) 15.0 windows version. The data were analysed using one-way analysis of variance (ANOVA) and group means were compared with LSD (Least Significant Difference) Post Hoc Test. Pvalues $<0.05$ were considered as significant.

\section{RESULTS}

The present study is based on the combined effect of nifedipine and pentazocine against maximal electroshock induced seizures in rats, taking distilled water as control.

The results of Mean duration of convulsions (Table 1 and 2, Figure 1) shows that Group-4 (Nifedipine $10 \mathrm{mg} / \mathrm{kg} \mathrm{BW}$ and Pentazocine $30 \mathrm{mg} / \mathrm{kg} \mathrm{BW}$ ) animals were significantly $\mathrm{p}<0.001$ reduced compared to Group 1(distilled water). Group 4 showed significant $\mathrm{p}<0.05$ reduction compared to Group-2 (Nifedipine 10mg/kg BW) and Group-3 
(Pentazocine $30 \mathrm{mg} / \mathrm{kg} \mathrm{BW}$ ) respectively. There is no significant difference between the groups which received nifedipine and pentazocine alone. The duration of Tonic Hind Limb Extension (Table 1 and 2, Figure 2) in Group 4 reduced significantly $\mathrm{p}<0.001$ compared to Group 1-3 rats. In case of Recovery (Table 1 and 2, Figure 3) the duration was significantly reduced in Group $4(\mathrm{p}<0.001)$ compared to Group-1.

Table 1: Combined effect of nifedipine and pentazocine against MES induced convulsions in rats.

\begin{tabular}{|llll|}
\hline Group & $\begin{array}{l}\text { Duration (seconds) } \\
\text { convulsions }\end{array}$ & Tonic hind limb extension & Recovery \\
\hline Group 1 & $41.67 \pm 1.751^{\mathrm{a}}$ & $16.17 \pm 1.472^{\mathrm{a}}$ & $7.50 \pm 1.049^{\mathrm{a}}$ \\
\hline Group 2 & $38.50 \pm 1.871^{\mathrm{ac}}$ & $14.33 \pm 1.862^{\mathrm{b}}$ & $6.33 \pm 1.033^{\mathrm{ac}}$ \\
\hline Group 3 & $39.33 \pm 1.033^{\mathrm{bc}}$ & $14.17 \pm 1.472^{\mathrm{b}}$ & $6.17 \pm 1.169^{\mathrm{bc}}$ \\
\hline Group 4 & $36.33 \pm 1.751^{\mathrm{d}}$ & $10.33 \pm 1.633^{\mathrm{c}}$ & $5.17 \pm 1.169^{\mathrm{bc}}$ \\
\hline
\end{tabular}

The data are expressed as Mean \pm SD, $n=6$ in each group, ANOVA and group means were compared with LSD Post hoc Test. P-value $<0.05$ were considered as significant.

Table 2: Multiple Comparison with LSD post hoc test showing significant difference between the Groups.

\begin{tabular}{|c|c|c|c|}
\hline Variable & Groups & & P-value \\
\hline \multirow{6}{*}{$\begin{array}{l}\text { Duration of } \\
\text { Convulsion }\end{array}$} & \multirow{3}{*}{ Group 1} & Group 2 & $<0.003 *$ \\
\hline & & Group 3 & $<0.023 *$ \\
\hline & & Group 4 & $<0.000 * *$ \\
\hline & \multirow{2}{*}{ Group 2} & Group 3 & 0.388 \\
\hline & & Group 4 & $<0.033^{*}$ \\
\hline & Group 3 & Group 4 & $<0.005^{*}$ \\
\hline \multirow{6}{*}{$\begin{array}{l}\text { Duration of } \\
\text { THLE }\end{array}$} & \multirow{3}{*}{ Group 1} & Group 2 & 0.064 \\
\hline & & Group 3 & $<0.045^{*}$ \\
\hline & & Group 4 & $<0.000 * *$ \\
\hline & \multirow{2}{*}{ Group 2} & Group 3 & 0.860 \\
\hline & & Group 4 & $<0.000 * *$ \\
\hline & Group 3 & Group 4 & $<0.001 * *$ \\
\hline \multirow{6}{*}{$\begin{array}{l}\text { Duration of } \\
\text { Recovery }\end{array}$} & \multirow{3}{*}{ Group 1} & Group 2 & 0.083 \\
\hline & & Group 3 & 0.050 \\
\hline & & Group 4 & $<0.002 * *$ \\
\hline & \multirow{2}{*}{ Group 2} & Group 3 & 0.797 \\
\hline & & Group 4 & 0.083 \\
\hline & Group 3 & Group 4 & 0.133 \\
\hline
\end{tabular}

**significantly different at $\mathrm{p}<0.001$, *significantly different at $\mathrm{p}<0.05 . \mathrm{n}=6$ in each group.

The Combination of nifedipine and pentazocine has synergistic effect. Thus it may be effective against MES induced convulsions in rats.

\section{DISCUSSION}

Stimulation of $\kappa$-opioid receptors in the brain results in MES seizure protection and suggests that endogenous $\kappa$ opioid system may be important in the regulation of cerebral activity (Dimorphic A which is known to be a putative endogenous ligand for the $\kappa$-receptor has been shown to attenuate MES seizures). The present study is based on the combined effect of nifedipine and pentazocine against MES induced seizures taking distilled water as control in rats. In MES method rats divided into control, nifedipine, pentazocine and nifedipine+pentazocine groups ( 6 animals in each group) are used. The mean duration of convulsion, duration of tonic hind limb extension, recovery with nifedipine and pentazocine independently was decreased compared to control (as per Table 1) when nifedipine and pentazocine were combined the decrease in mean duration of convulsion/tonic hind limb extension /recovery was much more compared to individual drugs. (nifedipine, pentazocine, control ) (as per Tables 1,2).

To test the variance and statistical significance the ANOVA test was used as there are 4 groups for comparison.

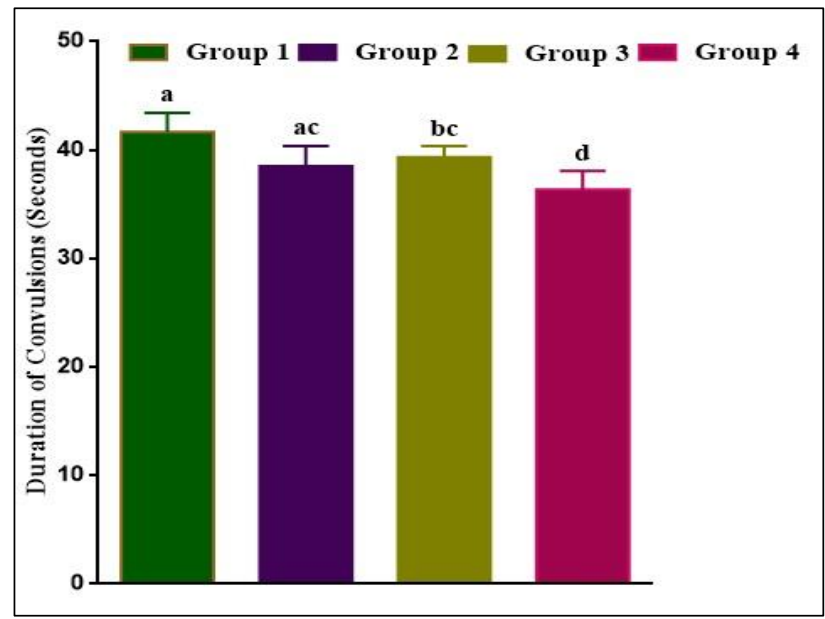

Figure 1: Duration of Convulsions (seconds) by MES method after 45 mins of drug administration. Data are the Mean \pm SD. P-value $<0.05$ were considered as significant. (ANOVA and group means were compared with LSD Post Hoc Test). 


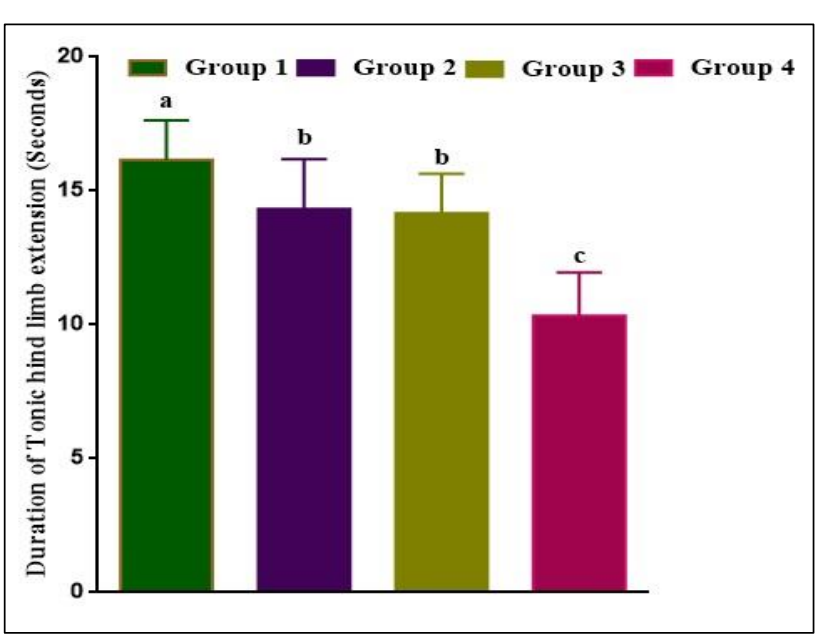

Figure 2: Duration of tonic hind limb extension (seconds) by MES method after 45 mins of drug administration. Data are the Mean \pm SD. P-value $<0.05$ were considered as significant. (ANOVA and group means were compared with LSD Post Hoc Test).

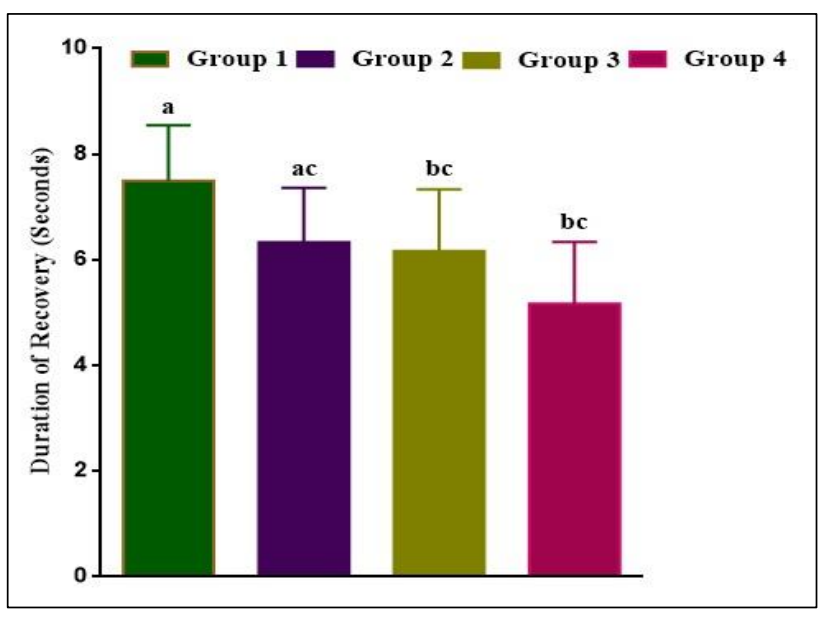

Figure 3: Duration of Recovery (seconds) by MES method after $\mathbf{4 5}$ mins of drug administration. Data are the Mean \pm SD. P-value $<0.05$ were considered as significant. (ANOVA and group means were compared with LSD Post Hoc Test).

For convulsion and hind limb extension in rats the $\mathrm{P}$ value was $<0.000$, whereas the recovery from convulsion was $<0.002$. Unpaired " $\mathrm{t}$ " test showed $\mathrm{P}$ value $<0.05$ for all three parameters (duration of convulsion, duration of hind limb extension, recovery ) with combined effect of nifedipine and pentazocine when compared with control. Based on the above findings nifedipine in combination with pentazocine reduced duration of convulsion, duration of tonic hind limb extension and recovery was fast from electrically induced convulsions. ${ }^{7}$ In view of promising results with pentazocine, the screening and evaluation of highly selective kappa opioid drugs may prove beneficial to the development of novel therapeutic approaches to epilepsy. ${ }^{8-10}$ This combination therapy may have important potential, especially in those patients in whom conventional therapy has been inadequate or in patients who are refractory to anticonvulsant treatment, or in cases of in treatable epilepsy. ${ }^{11,12}$ Thus, on the basis of present data and other studies it can be said that nifedipine in combination with pentazocine may be effective against partial and generalized tonic clonic seizures. ${ }^{12,13}$ The experiment showed that nifedipine and pentazocine has independently reduced the duration of convulsion, duration of tonic hind limb extension and recovery was fast from electroshock. ${ }^{14}$

\section{CONCLUSION}

Based on previous studies which suggested that nifedipine and pentazocine has got anticonvulsant action, the present study was conducted to see the combined effect of nifedipine and pentazocine as anticonvulsant in experimentally induced convulsion in rats taking distilled water as control. Convulsion were induced electrically (Using Maximal Electroshock) by Electroconvulsometer. But when combined (nifedipine and pentazocine ) there was an improved effect in duration of convulsion/ tonic hind limb extension/ recovery when compared with that of control, nifedipine and pentazocine alone. The results obtained in this study provide supporting pharmacological evidence of efficacy, possible potential benefit of combining nifedipine with pentazocine in epilepsy. However, studies with other models of epilepsy, other Calcium channel blockers and other opioid drugs on experimental animals and human beings would be needed to substantiate the present work.

\section{ACKNOWLEDGEMENTS}

Author would like to thank Dr. N. Balakrishna (Scientist E, Department of Biostatistics, ICMR-National Institute of Nutrition, Hyderabad), Dr. B. Kavitha Devi (Assistant Professor, Department of Pathology, Osmania Medical College, Hyderabad) and Ms. T. Lalitha (Technical Assistant, PCT, ICMR- National Institute of Nutrition, Hyderabad) for their cooperation and help in the study.

Funding: No funding sources

Conflict of interest: None declared

Ethical approval: The study was approved by the Institutional Ethics Committee

\section{REFERENCES}

1. Bazil CW, Pedley TA. Advances in the medical treatment of epilepsy. Ann Rev Med. 1998;49(1):135-62.

2. Simon DS: The Treatment of Epilepsy. Blackwell Science Publishers, First Edition 1998.

3. Roger J. Porter, Brain S. Medlrum. Anti-epileptic drug. In: Basic and clinical pharmacology by Bertram.G., Katzung, Appleton and Lange, Connecticut. $11^{\text {th }}$ ed. San Francisco, McGraw-Hill; 2009: 399.

4. Pumani R. Kurlewizl, louvel J. Fast. Extracellular transients : involvement in epileptic processes. Science. Ind J Pharmacol. 2000;32:347-352. 
5. Tortella FC, Robles L, Holaday JW. U50 488 a highly selective Kappa opioid anticonvulsant effect in rats. Ind J Pharmacol. 1997;29:194-7.

6. Techno electronics. Lalbargh. Lucknow-226001 India. Available at: https://www.exportersindia.com/technoelectronics-lucknow/electro-convulsometer-lucknowindia-984056.htm.

7. Khanna N, Bhalla S, Verma V, Sharma KK. Modulatory effects of nifedipine and nimodipine in experimental convulsions. Ind $\mathbf{J}$ Pharmacol. 2000;32(6):347-52.

8. Anshu M, Sharma KK, Mediratta PK. The anticonvulsant effect of pentazocine against maximal electroshock seizure in mice. Ind $\mathbf{J}$ Pharmacol. 1997;29(3):194-97.

9. Damasceno DD, Ferreira AJ, Doretto MC, Almeida AP. Anticonvulsant and antiarrhythmic effects of nifedipine in rats prone to audiogenic seizures. Braz $\mathbf{J}$ Med Biol Res. 2012;45(11):1060-5.

10. Church J, Fletcher EJ. Blockade by sigma site ligands of high voltage-activated $\mathrm{Ca}^{2+}$ channels in rat and mouse cultured hippocampal pyramidal neurones. $\mathrm{Br}$ J Pharmacol. 1995;116(7):2801-10.

11. El-Azab MF, Moustafa YM. Influence of calcium channel blockers on anticonvulsant and antinociceptive activities of valproic acid in pentylenetetrazole-kindled mice. Pharmacological Reports. 2012;64(2):305-14.

12. Zamponi GW, Striessnig J, Koschak A, Dolphin AC. The physiology, pathology, and pharmacology of voltage-gated calcium channels and their future therapeutic potential. Pharmacological Reviews. 2015;67(4):821-70.

13. Khanna N, Khosla R, Kohli J. Opioid receptor mediated anticonvulsant effect of pentazocine. Ind $\mathrm{J}$ Med Sci. 1998;52(1):1-7.

14. Muralidhar C, Prasad VS, Sridhar I. Anticonvulsant effect of nifedipine, dizepam and in combination on pentylenetetrazol induced experimental models of epilepsy on albino rats. Int $\mathrm{J}$ Basic Clin Pharmacol. 2017;6:2577-82.

Cite this article as: Banjara SK, Namala B, Rajanna A. Combined anticonvulsant effect of nifedipine and pentazocine in experimentally induced seizures in rats. Int J Basic Clin Pharmacol 2019;8:1875-9. 